\title{
Management of Eumycetoma
}

\author{
Tjokorde Istri Nindya Vaniary, Sunarso Suyoso, Linda Astari, Yuri Widia, Sylvia \\ Anggraeni, Evy Ervianti \\ Department of Dermatology and Venereology, Faculty of Medicine Universitas Airlangga/Dr. \\ Soetomo General Academic Teaching Hospital, Surabaya, Indonesia
}

\begin{abstract}
Background: Mycetoma is a chronic inflammatory disease of the skin that can extend to the fascia, tendons, muscles, and bones. Caused by a bacterium called actinomycetoma and a fungus called eumycetoma are responsible for mycetoma, both of which must be distinguished because they require different medical therapy. Eumycetoma is a localized disease, chronic, and growing slowly. Most of eumycetoma patients had delays in seeking medical care. Purpose: To provide an overview and discuss various aspects of eumycetoma, including its epidemiology, etiology, pathogenesis, classification, clinical picture, diagnosis, differential diagnosis, and therapy. Review: Eumycetoma infection begins as infectious agents enter through the skin with a minor trauma caused by objects contaminated with fungi, forming granular or granulomatous lesions with tract and sinus in there. The infection can spread from the site of inoculation into the muscles and bones. The diagnosis is based on anamnesis (chronic and painless), the triad of tumefaction, draining sinuses and grains, and laboratory investigation. It's a difficult case, often recur and difficult to be surgical excisison, so that the best first option therapy is the combination of itraconazole and terbinafine itself as an alternative to surgical therapy at least 6 months. Conclusion: Eumycetoma is an infection caused by a fungus with granulomatous lesions with sinus formation and grains in it. The best first option therapy is the combination of itraconazole and terbinafine although it's still an early case.
\end{abstract}

Keywords: eumycetoma, actinomycetoma, fungal infection, management.

Correspondence: Evy Ervianti, Department of Dermatology and Venereology Faculty of Medicine, Universitas Airlangga / Dr. Soetomo General Academic Hospital, Jl. Mayjen Prof. Dr. Moestopo No. 6-8 Surabaya 60131, Indonesia. Phone: +62 85649410547, e-mail: evy_if@yahoo.com.

\section{INTRODUCTION}

Mycetoma is a chronic inflammatory disease of the skin that can extend to the fascia, tendons, muscles, and bones. It is contracted almost worldwide, particularly in tropical and subtropical countries. ${ }^{1-3}$ Prasetyo AD and Suyoso S reported that there were 32 subcutaneous mycoses patients in 2000-2009 at the Dr. Soetomo Hospital Surabaya. Eumycetoma contributes to $5(15.9 \%)$ cases out of 32 patients, and most patients presented with particular anamnesis, clinical, and histological features. ${ }^{4}$

Initially, mycetoma occurs as a chronic infection that causes inflammation in the subcutaneous tissue. It is usually preceded by a history of trauma. Mycetoma can be caused by a bacterium called actinomycetoma or a fungus called eumycetoma. Thorough physical examinations, laboratory evaluations, and additional imaging are the keys to distinguish actinomycetoma from eumycetoma since the two require different treatment. ${ }^{5-8}$

Eumycetoma is a localized, chronic, and slowdeveloping disease. Eumycetoma affects both subcutaneous and cutaneous tissues accompanied by abscess and granuloma formation. Several studies reported that most patients had delays in seeking medical care due to the poor socio-economic condition, resulting in suboptimal care in health facilities. $^{7,9-11}$

This article discusses various aspects of eumycetoma, including its epidemiology, etiology, pathogenesis, classification, clinical feature, diagnosis, differential diagnosis, and therapy.

\section{BACKGROUND}

Eumycetoma is commonly found in tropical and subtropical countries such as Africa and India. Numerous cases have been reported from tourists who visited the endemic countries. Pseudallescheria boydii has been identified as the most common causative agent for eumycetoma in North America. Some fungi are reported to have a high frequency in certain geographical locations. Acremonium spp and Madurella grisea are frequently reported in South America, and Madurella mycetomatis is widely distributed nearly worldwide especially in India and Africa. ${ }^{12-15}$ In Surabaya, particularly at the Dr. 
Soetomo Hospital, eumycetoma contributes to 5 $(15.9 \%)$ out of 32 subcutaneous mycoses cases yearly in 2000-2009. ${ }^{4}$

There are at least 30 species of fungi that are related to human eumycetomas. The soil is a natural reservoir for most eumycetoma-causing fungi. More than $90 \%$ of eumycetomas worldwide are caused by 3 organisms, which are Madurella mycetomatis, Madurella grisae, and Scedosporium apiospermum. . $^{3,70}$

Eumycetoma is initially caused by the entry of infectious agents into the skin through a recurring minor trauma or penetrating trauma by an object that is contaminated with the causative fungus. It is a very slow infection process, taking months or years. It is presumed that failure in an effective active mobilization from phagocytic response provides sufficient time for the fungi to produce granules. It starts as nodules or granulomatous that contains sinus tracts. The infection can spread from the inoculation point to the muscles or, if prolonged, to the bones. The mainly hollow ones such as those on the ankle, wrist, and spine, or organs beneath the lesion. Cavities, also known as geodes (due to the similar mineralization process), will then form. ${ }^{7,15,16-17}$

Topographically, the fungus mostly affects foot soles $(80 \%)$, lower legs $(7 \%)$, and arms (6\%). In Mexico, the back is reported as the frequently infected area. Infection on the head, belly, and chest area is rarely found, usually related to an immunosuppressed condition. ${ }^{3,7}$ In Surabaya, there was a rare eumycetoma case on right waist area since 10 years with enterocutan and nephrocutan fistulae. ${ }^{18}$

\section{REVIEW}

Eumycetoma appears clinically as a non-painful swelling on the infected area, which will slowly develop into a solid, non-painful nodule that enlarges and ruptures on its surface, forming a sinus duct and tunnel to deeper tissues. This causes swelling and distortion on the lower limb. The feet soles tend to have a convex surface. The leg will swell even further and form an abscess. It will become painful and produce mucopurulent exudate that contains fungal colonies. The organisms also affect the subcutaneous connective tissues, bones (in certain types), and ligaments in an extended infection period, but rarely affects the tendons, muscles, and nerve tissues. Granules can be observed with both bare eyes and microscopic examination. The morphological and color characteristics of the granules are the keys to its identification. The granules consist of white, black, or brownish particles sized between 250-1000 $\mu \mathrm{m}$ that can be distinguished with bare eyes and shaped oval to globular. There is no cellular proliferation that the sinus edges are flat, level with the skin. ${ }^{1-3,7}$

In the diagnosis of eumycetoma, a thorough diagnosis starting from the symptom's characteristics (onset, location, quality, quantity, aggravating and extenuating factors, and concomitant symptoms) to the history of preceding diseases is important. Detailed anamnesis for a history of trauma is also crucial, considering the causative agents that have entered the host's body through trauma points. Familial history of malignancy is also a key anamnesis point to exclude the possibility of malignancy as a differential diagnosis. Socioeconomic status should be taken into consideration, minding that eumycetoma is closely related to occupations with high exposure to soil, such as farmers. ${ }^{11,12,19}$

A general physical examination covers the general condition and vital signs. It is essential to carefully evaluate the general condition, keeping in mind the possibility of malignancy. Inspection and palpation are done during the local status evaluation. A primary lesion invades the surrounding area, tumorlike in shape, non-painful, accompanied by subcutaneous swelling that slowly develops into larger and softer tissue, forming a phlegmon. Eumycetomas typically appear as swollen tissues or abscess that will rupture to the surface, forming sinuses. The surface of the lesion tends to appear bumpy, each of which contains a sinus end. Some patients may have macroscopic granules corresponding to the causative organism from the discharge through the sinuses. The sinus surface is level with the skin, usually black-colored. The bones are not usually involved. $3,11,12,19$

Additional examination is done to detect mycetoma granules, which is the key characteristic in the diagnosis, and it is usually excreted through an open sinus. Direct examination is done by directly evaluating the granules in the pus. The granules can also be collected by removing the crust from pustule or sinus surfaces by pressing gently using a sterile needle on the edges. The granules consist of white, black, or brownish particles, ranging from 250-1000 $\mu \mathrm{m}$ in size, that can be easily distinguished with bare eyes. Direct microscopic examination for granules is important as small actinomycete, or fungal elements will be visible. Generally, the two are indistinguishable by potassium hydroxide $(\mathrm{KOH})$ alone that a hematoxylin and eosin coloration is used. Additionally, black granules are always caused by fungi. ${ }^{1,2}$ Actually from the grains, we can diagnose a species, because each species of eumycetoma and 
actinomycetoma has different morphologic and spread on Saboraud's agar. It is important to plant characteristic and color of the grains. ${ }^{20}$ on several agar plates as this single species often

The last identification process, is done by isolating the causative fungi through culture. Considering the numerous possibilities of the species, it is necessary to use several different culture media as various incubation conditions. The morphological and physiological characteristics are functioned to distinguish the genus and species. A deep biopsy is the best method for culture because it minimizes contamination to the superficial tissue. The granules shall be cleaned with sterile saline solution, crumbled, shows the precise etiology. The agar plates shall be incubated at $25{ }^{\circ} \mathrm{C}$. Anaerobic procedure is not necessary as there are no obligate anaerobic fungi. The growth of eumycotic fungi is usually slow; therefore, the agar plates should be kept for 6-8 weeks. The identification shall be based on the morphology of the colony, types of conidia, and the pattern of assimilation. The production of conidia can be increased by growing on low-nutrient media, such as potato-carrot agar or cornmeal agar. ${ }^{3}$
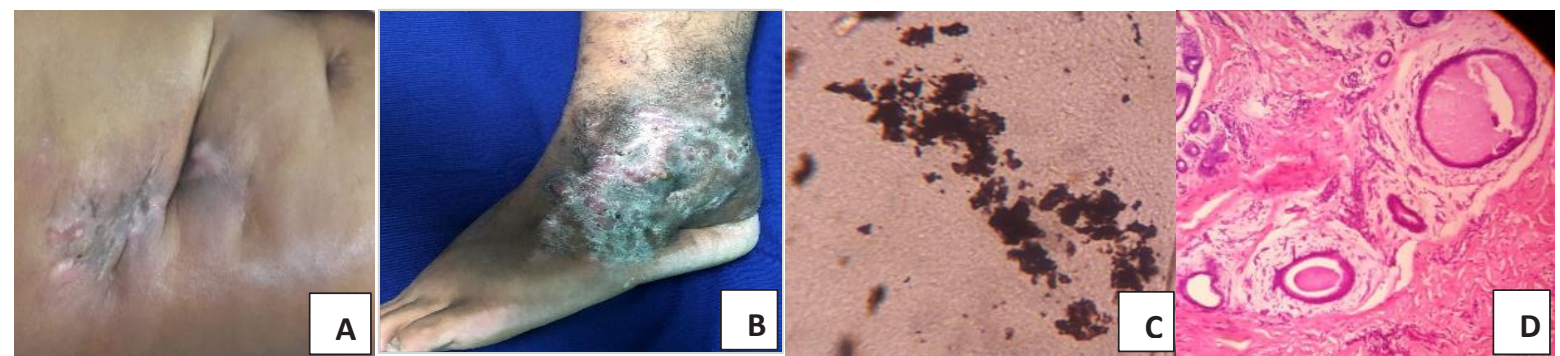

Figure 1. Eumycetoma. A, B. They show tumefaction, flat border around sinus opening on the skin surface. C. The morphologic characteristic and black color of grains show as Madurella mycetomatis. D. Histopathology (H\&E 400x) shows granules within granuloma. (Courtesy of Dr. Soetomo General Academic Hospital Surabaya)

A histological examination on indurated skin shows wide granulated tissue that contains abscess and might suggest a sinus. The appearance of a granulated tissue is unspecific. In the early stage of the disease, the surrounding tissue of the abscess contains lymphoid cells, plasma cells, histiocytes, and fibroblasts; however, fibroblasts might dominate in the late stage. The presence of granules confirms the diagnosis because granules almost exclusively appear in abscesses or sinuses, and the biopsy is done in a purulent area. Most granules are 0.5 to $2.0 \mathrm{~mm}$ in size, large enough to be seen with bare eyes. The coloring is done with Periodic Acid-Schiff (PAS), Grocott's methenamine-silver, hematoxylin and eosin method. Generally, eumycetoma granules consist of septate hyphae, which are 4-5 $\mu \mathrm{m}$ in size, have wide mycelium, light red-tinted on the surrounding area, and are surrounded by basophilic area. There is a strong or irregular basophilic formation in its center. On the other hand, actinomycetoma has bright irregular coloration, strong basophilic surrounding the granules, and wide-tufted eosinophil that acts as a border in the histological characteristic. Both eumycetoma and actinomycetoma have similar histological characteristics. Eumycetoma develops slowly and, in its chronic form, will be identified as a foreign object, followed by the formation of granuloma without caseation, and giant cells., 5,20
Radiologic evaluation is suggested particularly to evaluate and identify the involvement of bones. CT scans can show bone destruction, periosteal reaction, erosion and trabecular formation, and granulomas. In eumycetoma, an abnormality in the case of lytic bones without hypertrophic effect might occur. CT scans can detect bone involvement since the early phase. It is also more reliable than MRI; therefore, it is ideal for staging. MRIs can be used to distinguish between other differential diagnoses, namely musculoskeletal tumors. . $^{3,21}$

Molecular evaluation method may not be reliable through morphology evaluation for genus and species identification considering the possible contamination by bacteria, giving a negative result, yet the culture is positive. The morphological structure is often hard to identify. Therefore, a molecular diagnosis, such as polymerase chain reaction (PCR), is utilized. PCR is available in various forms, including $\mathrm{PCR}$ restriction fragment length polymorphism (RFLP), real-time PCR, and DNA sequencing. These techniques help to identify the species from the lesion biopsy sample. . $^{3,7}$ Immunological methods such as enzyme-linked immunosorbent assay can be utilized to identify specific antibodies. ${ }^{3,7}$

The differential diagnosis for eumycetoma might vary according to its pathological appearance. In its early phase, eumycetoma lesions might represent 
granuloma, various benign and malignant neoplasm, conidiobolomycoses. Other possible differential and cystic lesion. A non-fistula lesion should be diagnoses include leishmaniasis, cutaneous distinguished from sporotrichosis, chromomycoses, or tuberculosis, and cellulitis. $3,7,14$

Table 1. The difference between eumycetoma and actinomycetoma ${ }^{3,7,22-24}$

\begin{tabular}{|c|c|c|c|}
\hline NO & CATEGORY & EUMYCETOMA & ACTINOMYCETOMA \\
\hline 1 & Epidemiology & More common in Africa and India & $\begin{array}{l}\text { More common in Central and South } \\
\text { America }\end{array}$ \\
\hline 2 & Causative agent & Fungi & Actinomycetes bacteria \\
\hline 3 & $\begin{array}{l}\text { Lesion } \\
\text { characteristics }\end{array}$ & Encapsulated and well-demarcated & Diffuse with unclear demarcation \\
\hline 4 & Sinus & $\begin{array}{l}\text { Few, sinus borders are level with the } \\
\text { skin }\end{array}$ & Lots, sinus borders are swollen, lip-like \\
\hline 5 & Granule color & $\begin{array}{l}\text { Varies, dominated by black, white, and } \\
\text { brownish color }\end{array}$ & $\begin{array}{l}\text { Varies from white, yellowish-white, light } \\
\text { red, red, cream, to brownish-yellow }\end{array}$ \\
\hline 6 & Filament width & $2-6 \mu \mathrm{m}$ or wider & $0.5-1 \mu \mathrm{m}$ \\
\hline 7 & $\begin{array}{l}\text { Radiological } \\
\text { findings }\end{array}$ & $\begin{array}{l}\text { Bone anomaly, in which lytic bones are } \\
\text { not accompanied by hypertrophic } \\
\text { effect }\end{array}$ & $\begin{array}{l}\text { More significant bone anomaly, in which } \\
\text { lytic bones are accompanied by } \\
\text { hypertrophic effect }\end{array}$ \\
\hline 8 & $\begin{array}{l}\text { Disease } \\
\text { progression }\end{array}$ & $\begin{array}{l}\text { Less severe inflammation, less } \\
\text { aggressive lesion, slower invasion to } \\
\text { bone structures }\end{array}$ & $\begin{array}{l}\text { More severe inflammation, more } \\
\text { aggressive lesion, rapid invasion to bone } \\
\text { structures }\end{array}$ \\
\hline 9 & $\begin{array}{l}\text { Disease } \\
\text { transmission }\end{array}$ & $\begin{array}{l}\text { Rarely disseminative, only invades the } \\
\text { primary location, slower spread to bone } \\
\text { structures }\end{array}$ & $\begin{array}{l}\text { Disseminative and often causes a } \\
\text { secondary lesion to other skin areas, } \\
\text { rapidly spread to bone structures } \\
\text { Uncomplicated: }\end{array}$ \\
\hline 10 & $\begin{array}{l}\text { Gold } \\
\text { therapy }\end{array}$ & $\begin{array}{l}\text { 1. Itraconazole } \\
\text { 2. Ketoconazole } \\
\text { 3. Combination of itraconazole and } \\
\text { terbinafin as an alternative to } \\
\text { surgical therapy }\end{array}$ & $\begin{array}{l}\text { 1. Trimethoprim-sulfamethoxazole } \\
\text { (TMP-SMX)/ co-amoxiclav } \\
\text { 2. Combination of dapsone/ rifampicin } \\
\text { and TMP-SMX/co-amoxiclav } \\
\text { Complicated: } \\
\text { 1. Amikacin-TMP-SMX/co-amoxiclav } \\
\text { (Welsh's regiment) } \\
\text { 2. Amikacin } \\
\text { 3. Amikacin-imipenem } \\
\text { 4. Linezolide }\end{array}$ \\
\hline 11 & $\begin{array}{l}\text { Management } \\
\text { strategy }\end{array}$ & $\begin{array}{l}\text { Both medication and surgical treatment } \\
\text { are necessary. } \\
\text { In a surgical-only strategy for small, } \\
\text { encapsulated lesions, } 90 \% \text { of cases will } \\
\text { recur. Medication-only strategy only } \\
\text { results in partial improvement. } \\
\text { Medications are recommended both } \\
\text { before surgery to prevent local } \\
\text { proliferation and as its therapy itself, } \\
\text { and after surgery to prevent a } \\
\text { recurrence. }\end{array}$ & $\begin{array}{l}\text { Medication only is sufficient. More } \\
\text { severe cases possibly need a combined } \\
\text { medication-surgery strategy. Surgical- } \\
\text { only treatment is not indicated. } \\
\text { Medications-only therapy is effective for } \\
\text { almost all cases. }\end{array}$ \\
\hline
\end{tabular}

The therapy for eumycetoma is quite challenging. The lack of education and economic resources largely have caused delays in medical evaluation and treatment. Even when the diagnosis is confirmed in the early stages, patients are usually reluctant to seek treatment. This might cause significant functional disability and limb amputation in the future. Therefore, a comprehensive treatment strategy accompanied by social and economic support is crucial. ${ }^{15,25}$ 
Eumycetoma tends to be resistant to medicationonly treatment, especially in patients in the late stages. Thus, the best option for eumycetoma therapy is a combination of medications and surgical strategy. ${ }^{15,25}$

Ketoconazole for the treatment of eumycetoma caused by Madurella mycetomatis is effective in more than $70 \%$ of patients. Ketoconazole is well-absorbed medication, and an acidic environment is ideal for its optimal absorption. Achlorhydric environment and anti-gastric acid secretion drugs (such as antacids, anticholinergics) interferes absorption. In general, it is metabolized by the liver, turned into inactive metabolites, and excreted along with bile acids into the digestive tract. The effective dose for ketoconazole is $400 \mathrm{mg} /$ day $(10 \mathrm{mg} / \mathrm{kg} /$ day $)$ not devided dose or repeated monthly, given for 9 to 12 months or more. Commonly reported side effects are endocrine changes, gynecomastia, and impaired liver function. Ketoconazole should not be used as first-line therapy, and it shall only be taken if the patient is unable to consume other antifungal agents. ${ }^{6-7,26-27}$

A recent therapy with a triazole antifungal group for eumycetoma bore a more effective result, less drug interaction, and fewer side effects. Itraconazole is a cytochrome P-450-dependent agent that inhibits ergosterol synthesis, affecting the cell membrane and fungal growth. Itraconazole is consumed $200-400 \mathrm{mg}$ daily for 6 months. Itraconazole produces a fibrous capsule around the lesion, facilitating the following local excision procedure. A $200-400 \mathrm{mg}$ itraconazole therapy is then prescribed until recovery. Recovery means the disappearance of all masses or sinuses, normal findings in ultrasonography evaluation, and negative results in mycology evaluation. The bioavailability of Itraconazole varies, and its absorption is gastric acidity- and food-dependent. Itraconazole should not be given to patients with ventricular dysfunction and congestive heart failure. It can be consumed for up to 3 months postoperatively or after recovery because it reduces the risk of recurrence. ${ }^{6-7,26,28}$

Eumycetoma also responds well upon therapy with Imidazole antifungal groups, namely posaconazole and voriconazole. Posaconazole is available in $40 \mathrm{mg} / \mathrm{ml}$ suspension. Posaconazole is given $200 \mathrm{mg}$ orally 4 times daily for refractory fungal infections to other antifungal agents. It should be taken with food or food supplements to enhance absorption. The pharmacological action is CYP450 inhibition through $14 \mathrm{a}$-sterol demethylase, which is crucial for the fungal synthesis of ergosterol from lanosterol. Voriconazole is a triazole antifungal agent and a derivative of fluconazole. Its mechanism of action is similar to that of posaconazole. Voriconazole is available in 50 or $200 \mathrm{mg}$ tablets, $40 \mathrm{mg} / \mathrm{ml}$ suspension, and $200 \mathrm{mg}$ powder in a vial for injection. Voriconazole should not be prescribed with a high dose of ritonavir and rifampicin. The most common side effects include visual disturbances, fever, rash, vomiting, nausea, diarrhea, headache, sepsis, peripheral edema, abdominal pain, and respiratory disorders. Liver function should be closely monitored in posaconazole use. The therapy should be stopped in the case of a severe liver abnormality. Posaconazole and voriconazole serve as second-line therapy. ${ }^{7,26-27}$

In the use of azoles, the presence of drug interaction should be noted. Antacids might reduce azoles absorption. Azoles might cause edema if prescribed together with calcium channel inhibitors such as amlodipine or nifedipine. Azoles might induce hyperglycemia if taken with sulfonylureas. In a high dose consumption, azoles might increase the plasma concentration of tacrolimus and cyclosporines. Cases of rhabdomyolysis have been reported in the use of azoles along with lovastatin and simvastatin. Cardiac arrhythmia might occur in the use of azoles with cisapride. Azoles also increase the plasma concentration of midazolam and triazolam. The plasma concentration of azoles might be lower if taken with phenytoin, rifampicin, and $\mathrm{H} 2$ receptor antagonists. Imidazole might enhance the effect of warfarin (anticoagulant) if taken simultaneously; therefore, it needs to be monitored closely. ${ }^{7,26-27}$

Terbinafine is an allylamine that inhibits squalene epoxidase, causing sterol deficiency in the fungal cell membrane and toxic accumulation of squalene. To date, there have not been any absolute contraindication for its use with other drugs; however, the use with other hepatotoxic or nephrotoxic agents should be avoided. The frequently reported side effects are headache, diarrhea, nausea, dyspepsia, urticaria, and pruritus. Some researchers also reported other complaints, including fatigue, tasting disorders, erectile disorders, and elevated liver function tests. ${ }^{5,7,26-27}$

Prompt diagnosis, and surgery are possible before the lesion expands and reaches the bones because eumycetoma lesion is well-demarcated. The surgical resection should be done up to the surrounding normal tissues extensively. Several surgical strategies include debridement, wide excision, and amputation. The recurrence number after simple resection in eumycetoma is considerably high; therefore, amputation is often needed. . $^{3,8,21}$

The highest recovery number is achieved with a combination of medication and surgery, particularly in entirely resectable lesions. The early treatment options are terbinafine and itraconazole. The therapy is halted 
once all sinuses are completely healed, no clinically and radiologically visible masses, and no findings of granuloma in histopathology and causative fungi in culture. . $^{3,8,21,23}$

Terbinafine is offered as an alternative to surgical therapy because it binds strongly to serum protein, skin, or subcutaneous tissue, but only in immunocompetent patient. ${ }^{23}$

Eumycetoma is a difficult case, often recur and difficult to surgical therapy, so that it is better directly to give itraconazole (400 $\mathrm{mg}$ daily) along with terbinafine (500-750 mg daily) at least 6 months, although it is still an early case. ${ }^{23}$

Before the surgical treatment for eumycetoma, the patients are given terbinafine (500-750 mg/daily) along with itraconazole (400 mg daily) for 6 to 12 weeks, continued postoperatively until full recovery or the occurrence of side effects. ${ }^{7,18,26-27}$

In several untreated eumycetoma cases, the disease will progress slowly, although some will develop destructively into chronic cases. Eumycetomas that are not treated with antifungal agents would initially appear as a non-painful mass, but slowly develop and damage the bones, muscles, or surrounding tissue to the point of amputation. On late phases, eumycetomas might cause complications, namely secondary bacterial infection that induces bacteremia and septicemia, leading to death. . $^{3,10,11}$

A recently published prospective study investigated the prognostic factors for recovery and amputation. The study involved 1242 patients with eumycetoma and 302 patients with actinomycetoma. Long-term therapy and infrequent history of relapses were the significant prognostic factors for recovery. Lesions sized $5-10 \mathrm{~cm}$ or larger than $10 \mathrm{~cm}$, and a combination of medications and surgery were the significant predictors for a better chance of recovery. Prompt treatment would result in better development and minimized economic and social burdens. , $^{3,10,11}$

Eumycetoma is caused by fungi and its clinical appearance, including localized swelling on the infected area that slowly develops into a solid, nonpainful nodule that enlarges and ruptures its surface forming sinuses and tunnels to deeper tissues, causing swelling and distortion. The sinus borders are level with the skin, do not form a lip-like swelling, and produce granules. The diagnosis of eumycetoma is confirmed with anamnesis (chronic and painless), physical (the triad of tumefaction, draining sinuses level with the skin, and grains) and additional evaluation, including direct examination (each grains has different morphologic characteristic and color which shows a species of eumycetoma or actinomycetoma), culture (not always grow), histopathological (shows granuloma without caseation), radiological (lytic bone without hypertrophic effect), molecular and immunological evaluation (not always be done).

Eumycetoma is treated with a combination of pharmacological and surgical strategy. Directly to give itraconazole along with terbinafine itself as an alternative to surgical therapy although it is still an early case, at least 6 months. Prior to surgery, the patient should take terbinafine (500-750 mg daily) along with itraconazole (400 $\mathrm{mg}$ daily) for 6 to 12 weeks, also as its treatment itself continued postoperatively until full recovery or the occurrence of side effects.

\section{REFERENCES}

1. Bravo FG, Arenas R, Sigall DA. Actinomycoses, nocardiosis, and actinomycetoma. In: Kang S, Amagai M, Bruckner AL, Enk AH, Margolis DJ, McMichael AJ, Orringer JS. Editors. Fitzpatricks's dermatology in general medicine. $9^{\text {th }}$ ed. New York: Mc Graw-Hill; 2019. p. 287690.

2. Hay RJ. Deep fungal infections. In: Kang $\mathrm{S}$, Amagai M, Bruckner AL, Enk AH, Margolis DJ, McMichael AJ, Orringer JS. Editors. Fitzpatricks's dermatology in general medicine. $9^{\text {th }}$ ed. New York: Mc Graw-Hill; 2019. p. $2965-$ 85.

3. Mohamed HT, Fahal A, Sande WWJ. Mycetoma: epidemiology, treatment challenges, and progress. Res Rep Trop Med 2015; 6:31-6.

4. Prasetyo AD, Suyoso S. Studi retrospektif kasus mikosis subkutis di Instalasi Rawat Inap Kesehatan Kulit dan Kelamin RSUD Dr. Soetomo Surabaya yang dirawat selama periode 1 Januari 2000 sampai dengan 31 Desember 2009. Berkala Ilmu Kesehatan Kulit dan Kelamin. Surabaya 2010; 23(1): 17-24.

5. Hinshaw MA, Longley BJ. Fungal Disease. In: Elder DE, Elenitsas R, Rosenbach M, Murphy GF, Rubin Ai, $\mathrm{Xu} \mathrm{X}$, editors. Lever's Histophatology of the Skin. $11^{\text {th }}$ ed. Philadelphia: Wolter Kluwer; 2015. p. 3961-65.

6. Widaty S. Obat Antijamur pada mikosis profunda. Dalam: Bramono K, Suyoso S, Widaty S, Ramali LM, Siswati AS, Ervianti E, editor. Mikosis profunda. Edisi pertama. Surabaya: Airlangga University Press; 2019. h.141-58.

7. Estrada R, Chavez-Lopez G, Estrada-Chavez G, Lopez-Martinez R, Welsh O. Eumycetoma. Clin Dermatol 2012; 30: 389-96.

8. Welsh O, Salinas-Carmona MC, Garza JAC, Rodriguez-Escamilla IM, Sanchez-Mezza E. 
Current treatment of mycetoma. Curr Treat Options Infect Dis 2018; 10: 389-96.

9. Brufman T, Ben-Ami R, Mizrahi M, Bash E, Paran Y. Mycetoma of the foot caused by Madurella mycetomatis in migrants from Sudan. IMAJ 2015; 17: 418-20.

10. Mhmoud NA, Ahmed SA, Fahal AH, Hoog GS, Ende AHG, Sande WWJ. Pleurostomophora ochracea, a novel agent of human eumycetoma with yellow grains. J Clin Microbiol 2012; 50(9): 2987-94.

11. Ali A, Khadda S, Yadav AK, Parmar A, Sakhrani JK, Kapoor A. Giant eumycetoma gluteal region: excision and V-Y flap advancement.Int J Sci Rep 2015; 1(2): 146-7.

12. Nenoff P, Sande WWJ, Fahal AH, Reinel D, Schöfer H. Eumycetoma and actinomycetoma: an update on causative agents, epidemiology, pathogenesis, diagnostics, and therapy. JEADV 2015; 29(10): 1873-83.

13. Kothiwala SK, Purohit S, Meena M, Jindal A. Black grain eumycetoma of the breast misdiagnosed as fibroadenoma. IJDVL 2015; 81(5): 521-3.

14. Nenoff P, Sande WWJ, Fahal AH, Reinel D, Schofer H. Eumycetoma and actinomycetoma-an update on causative agents, epidemiology, pathogenesis, diagnostics and therapy. J Eur Acad Dermatol Venereol 2015; 29:1873-83.

15. Estrada R, Chávez-López G, Estrada-Chávez G, López-Martínez R, Welsh O. Eumycetoma. J Clin Dermatol 2012; 30: 389-96.

16. Thilakavathy P, Vijaykumar GS, Janagond AB, Vithiya G, Yegumuthu K. A Case report of eumycetoma: emphasizing the need for early diagnosis and appropriate management. Sch J Med Case Rep 2015; 3(3): 225-7.

17. Sampaio FM, Galhardo MC, Quintella LP, Souza PR, Coelho JM, Valle AC. Mycetoma by Madurella mycetomatis with 30 years of evolution: a therapeutic challenge. An Bras Dermatol 2013; 88(6 Suppl 1): 82-4.

18. Herwanto N, Hidayati A N, Ervianti E, Suyoso S. Enterocutan and nephrocutan fistule : a rare complication of eumycetoma (freepaper presentation). The $6^{\text {th }}$ Asia Pacific Society for Medical Mycology Congress. 2016, October 20 22; Bali; Indonesia
19. Belkum A, Fahal A, Sande WWJ. Mycetoma caused by Madurella mycetomatis: a completely neglected medico-social dilemma. In: N. Curtis, editor. Hot topics in infection and immunity in children. $9^{\text {th }}$. New York : Springer Science \& Business Media; 2013. p.179-89.

20. Suyoso S, Bramono K, Widaty S, Ervianti E, and Astari L. Laboratory diagnose of subcutaneous mycoses (Workshop). The $23^{\text {rd }}$ Regional Conference of Dermatology and the $16^{\text {th }}$ Annual Scientific Meeting of the Indonesian Society of Dermatology and Venerology 2018, August 8-11; Surabaya, Indonesia.

21. Sakayama K, Kidani T, Sugawara Y, Fujibuchi T, Miyawaki J, Miyazaki $\mathrm{T}$, Yamamoto $\mathrm{H}$. Mycetoma of foot: a rare case report and review of the literature. Foot Ankle Int 2014; 25(1): 7637.

22. Welsh O, Vera-Cabrera L, Welsh E, Salinas MC. Actinomycetoma and advance in its treatment. Clin Dermatol 2012; 30: 372-81.

23. Miranda E. Eumisetoma. Dalam Bramono K, Suyoso S, Widaty S, Ramali LM, Siswati AS, Ervianti E, editor. Mikosis Profunda edisi pertama, Surabaya; Airlangga University Press; 2019: 41-52.

24. Bramono K. Aktinomisetoma. Dalam Bramono K, Suyoso S, Widaty S, Ramali LM, Siswati AS, Ervianti E, editor. Mikosis Profunda edisi pertama. Surabaya; Airlangga University Press; 2019: 53-64.

25. Reis CMS, Reis-Filho EGM.Mycetomas: An epidemiological, etiological, clinical, laboratory, and therapeutic review. An Bras Dermatol 2018; 93(1): 08-18.

26. Welsh O, Al-Abdely HM, Salinas-Carmona MC, Fahal AH. Mycetoma medical therapy. PLoS Negl Trop Dis 2014; 8(10): 1-8.

27. Mhmoud NA, Fahal AH, Mahgoub ES, Sande WWJ. The combination of amoxicillin-clavulanic acid and ketoconazole in the treatment of Madurella mycetomatis eumycetoma and Staphylococcus aureus co-infection. PLoS Negl Trop Dis 2014; 8(6): 1-5.

28. Agarwal P, Agarwal US, Gupta R. Eumycetoma foot: successful treatment with combination of itraconazole and potassium iodide. Indian $\mathrm{J}$ Dermatol 2018; 1(2): 53-5. 